\title{
Exporting, Importing, and Firm Performance: Evidence from Thai Manufacturing
}

\author{
Thanapol Srithanpong ${ }^{1}$ \\ ${ }^{1}$ Graduate School of Business and Commerce, Keio University, Tokyo, Japan \\ Correspondence: Thanapol Srithanpong, Graduate School of Business and Commerce, Keio University, Tokyo, \\ Japan. E-mail: thanapol.srithanpong@outlook.com
}

Received: October 9, 2014

Accepted: October 14, 2014

Online Published: November 25, 2014

doi:10.5539/ijef.v6n12p71

URL: http://dx.doi.org/10.5539/ijef.v6n12p71

\begin{abstract}
This study examines the relationship between exporting, importing, and firm performance using a firm-level panel data set from the Manufacturing Industry Survey of Thailand from 1999 to 2003 . We mainly divide our analysis into three parts. First, we evaluate export and import premia for different measures of firm performance such as employment, value added per worker, capital per worker, average wages, and sales. Second, we test for export and import premia by running regressions of different performance measures on export and import status using probit and logit models to compare results. Third, we examine whether exporting and importing activities improve productivity at the firm level. The results reveal that, on average, exporters and importers are more productive, more capital-intensive, have more employees and total sales, and pay higher average wages than those of domestic counterparts. By various measures, exporters tend to be the most productive group of firms, followed by importers, and then firms that do not trade internationally. The results suggest that there might be a strong positive correlation between exporting and productivity and a weak positive correlation between importing and productivity at the firm level in Thai manufacturing.
\end{abstract}

Keywords: exporting, importing, firm performance, productivity, Thailand

\section{Introduction}

In several countries, rigorous ongoing discussions and examinations regarding the role of exports in promoting growth and productivity have been taking place (Greenaway \& Kneller, 2007). A large and growing body of empirical evidence has documented many superior characteristics of exporters compared with non-exporters and a broad number of studies have found that exporting firms are generally more productive, more capital-intensive, and pay higher average wages than firms that produce solely for the domestic market (Hahn, 2005). In recent times, there has been growing interest in examining the connection between exporting and productivity in both developing and developed countries. Initially, many studies uncovered evidence supporting self-selection but not learning-by-exporting (e.g., Clerides et al., 1998; Bernard \& Jensen, 1999b; Aw et al., 2000; Arnold \& Hussinger, 2005). Nevertheless, some studies also uncovered evidence of both self-selection and learning-by-exporting effects (e.g., Girma et al., 2004; Hahn, 2005; Fernandes \& Isgut, 2005; Van Biesebroeck, 2005). Therefore, the empirical evidence is rather diverse, which might suggest that the effects vary by the business, cultural and economic environment of each country (Bigsten \& Gebreeyesus, 2009).

Although the relationship between exports and productivity is one of the key subjects in the recent literature on international trade, the relationship between imports and productivity is not being focused with the same emphasis. Additionally, empirical evidence for the relationship between imports and productivity in many developing economies is extremely scarce. Nevertheless, with current datasets that incorporate variables on imports at the establishment level becoming accessible and measureable for several countries, another literature that focuses on the relationship between imports and productivity is growing in popularity (Wagner, 2012a). Moreover, empirical evidence from many countries widely suggests that exporting firms (and/or importing firms) are more productive than non-exporting (and/or non-importing) firms (Wagner, 2012b). This could be a result of either more productive firms becoming exporters, or export (import) activity increasing productivity.

Despite the significance of these issues regarding the effects of exports and imports on firm productivity, empirical evidence in Thai manufacturing concerning the topic is scarce, partly because of the lack of complete long panel data. Moreover, the dynamic relationship between increased trade and long-term output and growth in 
productivity is not yet well understood in Thailand. To contribute to this emerging body of knowledge, the present paper empirically examines the relationship between exporting, importing, firm performance, and productivity using a firm-level panel data set from the Manufacturing Industry Survey of Thailand from 1999 to 2003. We divide our analysis into three parts. First, we measure export and import premia for different firm performance measures, such as employment, value added per worker, capital per worker, average wages, and sales. Second, we extend our test for export and import premia by running regressions of different performance measures on export and import status using probit and logit models to compare results. Third, we examine whether exporting and importing activities improve output and productivity at the firm level.

Thailand, one of the fastest growing countries in Southeast Asia, can be considered an interesting case study to illustrate the issue at hand since evidence on the relationship between exporting, importing, and firm productivity in developing countries is still relatively scarce. Moreover, most productivity studies have focused on developed countries with greater available data. In addition, the manufacturing sector in Thailand is also dynamic, having experienced exceptionally strong growth since the 1990s. The results obtained from this study may provide possible applications for other developing countries.

\section{Methodological Issues and Recent Literature}

Since the seminal papers by Bernard and Jensen (1999a \& 2004) were released, many studies have demonstrated that exporting firms and non-exporting firms are fairly dissimilar. In theory, there are two important hypotheses for the relationship between exporting and productivity: self-selection and learning-by-exporting (Bigsten \& Gebreeyesus, 2009). Self-selection emphasizes that firms which become exporters are more productive from the first place and are, thus, more likely to be able to successfully enter the export market. On the other hand, learning-by-exporting claims that exporters improve their productivity by entering foreign markets, which increases competitive pressures and enables exporters to exploit economies of scale at the same time. Hence, the two hypotheses are also likely to be connected in that high productivity firms which can afford the extra cost of entry into export markets may still enhance their performance and productivity due to exporting.

Regarding the investigation into the relationship between exporting and productivity, a commonly used approach to examine differences in productivity between exporters and non-exporters is to follow (sometimes with extensions and modifications) the methodology introduced by Bernard and Jensen (1999a \& 1999b). Here, one starts by exploring the differences in average labor productivity (value added per worker) or average total factor productivity between exporters and non-exporters. The next stage is the calculation of exporter premia, defined as the percentage difference of labor productivity between exporters and non-exporters (Wagner, 2007). These premia are evaluated from a regression of labor productivity on the current export status and a set of control variables (typically including year, region, industry, firm size measured by the number of employees). The equation can simply be written as follows:

$$
\ln L P_{i t}=\beta_{0}+\beta_{l} \text { Export }_{i t}+\beta_{2} \text { Control }_{i t}+e_{i t}
$$

where $i$ is the index of the firm or plant, $t$ is the index of the year, $L P$ is labor productivity, Export is a dummy variable for export status ( 1 if the firm exports in year $t, 0$ otherwise), Control is a vector of control variables (industry dummies, dummies for regions, firm size, and year dummies), and $e$ is an error term.

The export premia, calculated from the estimated coefficient $\beta_{1}$, demonstrates the average percentage difference between exporters and non-exporters that controls for the characteristics included in the Control vector (Wagner, 2007). An alternative of (1) is usually estimated with fixed or random effects to control for unobserved firm or plant heterogeneity due to time-invariant firm characteristics that might be correlated with the variables included in the empirical model, and that might result in biased estimates of the exporter premia (Wagner, 2007). In our study, we carefully analyze the differences in performance between exporters (importers) and non-exporters (non-importers), using firm-level data from the Thai manufacturing sector, while controlling for firm characteristics. In contrast to previous studies, we explicitly take into account the role of both exporting and importing on firm performance and productivity in the Thai case. We also make use of the panel nature of our data by comparing the performance pattern of groups of exporting and importing firms over a four-year window. This paper is one of the first studies for the Thai case that contributes to the literature by documenting the relationship between exports, imports and firm productivity in Thai manufacturing. In the following section, although we are not able to directly test in detail the two hypotheses mentioned above (self-selection and learning-by-exporting) due to data constraints, we are able to initially answer these three questions for the Thai case: Do exporting or importing firms perform better than domestic firms? Which type of international firms performs better: exporters or importers? Do exports or imports increase productivity? 


\section{Data Description and Variable Definition}

In this study, the Manufacturing Industry Surveys by the National Statistical Office (NSO) of Thailand from 1999, 2000, 2001, and 2003 are used. The electronic version of the survey is available only from 1991 to 2003 , but the quality of the survey prior to 1999 (1991-1995) is rather problematic in terms of completeness. Additionally, the industry classification code used in those surveys before 1999 is the prior system's industry classification code (TSIC: Thailand Standard Industrial Classification) which does not match with the new industry classification code (ISIC: International Standard Industrial Classification). Furthermore, these surveys are also subject to inconsistency in industry identification of samples. As a result, only the Manufacturing Industry Survey data during 1999, 2000, 2001, and 2003 are used effectively in this paper.

Originally, there were 8,552, 9,360, 9,294, and 8,862 entries in the 1999, 2000, 2001, and 2003 surveys, respectively. Of these, we only use observations which are enumerated in the survey (i.e. by a firm which actually exists and responds to the survey). The sample observations were therefore lowered to 8,552, 4,658, 4,962, and 8,862 observations in the 1999, 2000, 2001, and 2003 surveys, respectively. The survey was first cleaned up by identifying duplicated samples (i.e., observations belonging to the same firm which filled in the questionnaire using the same records). Following Kohpaiboon (2009), the procedure was to treat duplicates as the records that reported the same values of the five key variables of interest, namely, registered capital, output value, domestic sales, domestic raw materials, and imported raw materials. Second, firms which had provided unrealistic information such as a negative value added, unlikely initial capital stock and total sales (e.g., less than 100 baht) were all dropped from the sample observation. After the data-cleaning procedure, the total number of samples was reduced from 27,034 to 18,078 observations from a total of four years. Table 1 provides a summary of survey characteristics and the extent to which the survey represents the Thai manufacturing sector for this period. Ultimately, 19 industries are included in our analysis.

Table 1. Statistical summary of the key variables

\begin{tabular}{llccccc}
\hline Variable & Unit & Observations & Mean & Std. Dev. & Min & Max \\
\hline lnOutput (Total output) & $(\ln )$ baht & 18078 & 16.5179 & 2.4994 & 8.0064 & 25.2085 \\
lnVAL (Value added per worker) & $(\ln )$ baht & 18078 & 11.5541 & 1.5352 & -1.9461 & 18.4029 \\
lnK (Capital) & $(\ln )$ baht & 18078 & 15.9849 & 2.3500 & 5.1931 & 24.9428 \\
lnKI (Capital per worker) & $(\ln )$ baht & 18078 & 12.1303 & 1.7019 & 2.5903 & 18.7872 \\
$\operatorname{lnM}$ (Material) & $(\ln )$ baht & 18078 & 15.8708 & 2.7421 & 5.7038 & 25.0273 \\
$\operatorname{lnMI}$ (Material per worker) & $(\ln )$ baht & 18078 & 12.0162 & 1.9148 & 2.9312 & 19.0215 \\
$\operatorname{lnL}$ (Labor) & $(\ln )$ workers & 18078 & 3.8546 & 1.4098 & 1.0986 & 9.7658 \\
$\ln$ AvrWages (Average wages) & $(\ln )$ baht & 18078 & 10.8029 & 1.2651 & -3.4177 & 13.6703 \\
$\operatorname{lnSales~(Total~sales)~}$ & $(\ln )$ baht & 18078 & 16.5289 & 2.4954 & 8.0064 & 25.1659 \\
InAge (Operating years) & $(\ln )$ years & 18078 & 2.2751 & 0.7720 & 0.0000 & 4.5951 \\
Small (1-15 persons) & zero-one dummy & 18078 & 0.2889 & 0.4533 & 0.0000 & 1.0000 \\
Medium (16-100 persons) & zero-one dummy & 18078 & 0.6073 & 0.4884 & 0.0000 & 1.0000 \\
Large (more than 101 persons) & zero-one dummy & 18078 & 0.1039 & 0.3052 & 0.0000 & 1.0000 \\
EX (Exporting firm) & zero-one dummy & 18078 & 0.2877 & 0.4527 & 0.0000 & 1.0000 \\
IM (Importing firm) & zero-one dummy & 18078 & 0.3249 & 0.4686 & 0.0000 & 1.0000 \\
\hline
\end{tabular}

Note. Mean = simple average; Std. Dev. = standard deviation; Min = minimum; and Max = maximum.

For the computation of firm productivity, total sales net changes in inventories of a firm is used as a measure of output $(Y)$ and were deflated using industry specific whole sale price indices. Total employment at the firm level is used to capture the labor $(L)$ component, which includes both male and female workers. Total cost and purchase of materials and components are used to calculate the material $(M)$ component. The measure used for capital stock $(K)$ was constructed using the average value of fixed assets of firms at the beginning and at the end of each year. Due to the shortage of sample observations in some industries in the survey, we combined several similar industries into one industry classification for simplicity. Some industries are combined to achieve a sufficiently large number of observations and are only grouped together based on similarities in the type of activity and factor intensity. 


\section{Performance of Exporters/Importers versus Non-Exporters/Non-Importers}

\subsection{Exporters Perform Better-Export Premia}

The estimated results for export premia are reported in Table 2, we compare the average of certain indicators such as employment, value added per worker, capital per worker, average wages, and sales of exporters and non-exporters for four years. The details can be explained as follows.

Table 2. Exporter premia

\begin{tabular}{|c|c|c|c|c|}
\hline & \multicolumn{4}{|c|}{ Estimated Exporter Premia (\%) } \\
\hline & $\begin{array}{c}\text { No } \\
\text { control }\end{array}$ & $\begin{array}{c}\text { Industry } \\
\text { controlled }\end{array}$ & $\begin{array}{c}\text { Industry } \\
\text { and Region } \\
\text { controlled }\end{array}$ & $\begin{array}{c}\text { Industry, } \\
\text { Region, and } \\
\text { Size controlled }\end{array}$ \\
\hline \multicolumn{5}{|l|}{1999} \\
\hline Employment & $172.14 \%$ & $163.73 \%$ & $159.29 \%$ & $93.20 \%$ \\
\hline Value added per worker & $98.77 \%$ & $97.79 \%$ & $87.06 \%$ & $71.58 \%$ \\
\hline Capital per worker & $42.01 \%$ & $53.48 \%$ & $44.10 \%$ & $41.90 \%$ \\
\hline Average wages & $61.23 \%$ & $56.25 \%$ & $47.28 \%$ & $36.74 \%$ \\
\hline Sales & $271.77 \%$ & $262.79 \%$ & $246.62 \%$ & $162.67 \%$ \\
\hline \multicolumn{5}{|l|}{2000} \\
\hline Employment & $170.95 \%$ & $163.16 \%$ & $155.69 \%$ & $87.83 \%$ \\
\hline Value added per worker & $106.77 \%$ & $108.80 \%$ & $92.14 \%$ & $78.96 \%$ \\
\hline Capital per worker & $52.12 \%$ & $62.46 \%$ & $47.77 \%$ & $53.81 \%$ \\
\hline Average wages & $71.33 \%$ & $67.86 \%$ & $55.55 \%$ & $47.01 \%$ \\
\hline Sales & $283.16 \%$ & $278.17 \%$ & $252.82 \%$ & $170.28 \%$ \\
\hline \multicolumn{5}{|l|}{2001} \\
\hline Employment & $182.81 \%$ & $173.61 \%$ & $168.44 \%$ & $97.68 \%$ \\
\hline Value added per worker & $92.98 \%$ & $98.77 \%$ & $85.01 \%$ & $70.62 \%$ \\
\hline Capital per worker & $50.99 \%$ & $68.85 \%$ & $59.61 \%$ & $53.85 \%$ \\
\hline Average wages & $62.77 \%$ & $63.88 \%$ & $51.96 \%$ & $43.12 \%$ \\
\hline Sales & $284.82 \%$ & $282.64 \%$ & $262.32 \%$ & $173.01 \%$ \\
\hline \multicolumn{5}{|l|}{2003} \\
\hline Employment & $194.87 \%$ & $189.79 \%$ & $179.96 \%$ & $37.63 \%$ \\
\hline Value added per worker & $132.45 \%$ & $132.25 \%$ & $107.33 \%$ & $80.18 \%$ \\
\hline Capital per worker & $99.32 \%$ & $105.89 \%$ & $84.19 \%$ & $70.76 \%$ \\
\hline Average wages & $118.05 \%$ & $115.14 \%$ & $85.77 \%$ & $59.29 \%$ \\
\hline Sales & $340.07 \%$ & $335.37 \%$ & $297.34 \%$ & $120.39 \%$ \\
\hline
\end{tabular}

Note. All coefficients are significant at the 5 percent level or better.

To test for exporter premia, we run regressions of the different performance measures on export status with and without controls. We estimate the following regressions:

$$
\ln Y_{i}=\alpha+\beta \text { Export }_{i}+\gamma \text { Industry }_{i}+\text { SRegion }_{i}+\mu \text { Size }_{i}+\varepsilon_{i}
$$

where $Y_{\mathrm{i}}$ represents five measures of current performance: labor productivity (value added per worker), employment, capital intensity (capital per worker), average wages of production and non-production workers, and total sales. Export $\mathrm{i}_{\mathrm{i}}$ is a dummy variable for current export status ( 1 if a firm exports the products produced, 0 if otherwise). Industry $\mathrm{i}_{\mathrm{i}}$ and Region $_{\mathrm{i}}$ are dummy variables for the two-digit industry (total 19 industries) and region where a firm is located (total 6 regions - the six regions are Bangkok, Vicinity and Central, Northern, Northeastern, Southern, and Others). Size $e_{\mathrm{i}}$ denotes firm size, measured by number of employees: Small being 115 persons, Medium being 16-100, and Large being more than 101 persons.

The estimated results from Equation (2) are shown in Table 2 and confirm that exporters surpass non-exporters in terms of various characteristics for all years, even after controlling for industry, region, and firm size. Also, all coefficients on the export dummy variable are highly significant. Controlling for firm size greatly reduces the coefficient of the export dummy variable, which suggests that, to some extent, the common characteristics of exporters are inferable to their larger size (Hahn, 2005). In spite of this, the estimated export premia remain highly significant. Interestingly, when controlling for industry and region, exporters employ more workers by 
roughly 160 percent and report more sales by about 250 percent. Moreover, after controlling for industry, region, and size, the value added per worker of exporters is larger by approximately 70 percent, capital per worker by approximately 40 to 50 percent and average wages by approximately 40 to 50 percent.

From Table 2, exporters in Thai manufacturing exhibit significantly higher sales, capital-labor ratio, and labor productivity (value added per worker) level. Average wages are also higher for exporting firms compared to firms producing only for domestic markets. These findings suggest that significant firm sales and other performance gaps indeed exist between exporters and non-exporters. Generally, exporters have more workers, exhibit higher value added per worker, tend to be more capital-intensive, pay higher wages for both production and non-production workers, and have more sales. Exporters are bigger than non-exporters for all measures, especially for sales and employment. After controlling for industry, region, and size, exporters still perform better than non-exporters, and all differences are highly significant. These results are consistent and similar to those reported for Korea in Hahn (2005). Hence, the case for exporting firms being more productive and performing better than non-exporters is also true in Thai manufacturing.

\subsection{Importers Are also Better-Import Premia}

We now turn to the issue of whether importers are also better than non-importers. Similarly, to test for importer premia, we perform regressions of the different performance measures on import status with and without controls and estimate the following regressions:

$$
\ln Y_{i}=\alpha+\text { BImport }_{i}+\gamma \text { Industry }_{i}+\text { SRegion }_{i}+\mu \text { Size }_{i}+\sigma_{i}
$$

Import $t_{i}$ is a dummy variable for current import status ( 1 if a firm imports materials and components from foreign markets, 0 if otherwise). The estimated results from Equation (3) are reported in Table 3.

Table 3. Importer premia

\begin{tabular}{|c|c|c|c|c|}
\hline & \multicolumn{4}{|c|}{ Estimated Importer Premia (\%) } \\
\hline & $\begin{array}{c}\text { No } \\
\text { control }\end{array}$ & $\begin{array}{c}\text { Industry } \\
\text { controlled }\end{array}$ & $\begin{array}{c}\text { Industry } \\
\text { and Region } \\
\text { controlled }\end{array}$ & $\begin{array}{c}\text { Industry, } \\
\text { Region, and } \\
\text { Size controlled }\end{array}$ \\
\hline \multicolumn{5}{|l|}{1999} \\
\hline Employment & $116.58 \%$ & $111.72 \%$ & $105.93 \%$ & $49.57 \%$ \\
\hline Value added per worker & $88.32 \%$ & $80.73 \%$ & $67.52 \%$ & $52.52 \%$ \\
\hline Capital per worker & $50.04 \%$ & $53.35 \%$ & $42.88 \%$ & $40.27 \%$ \\
\hline Average wages & $67.58 \%$ & $54.01 \%$ & $41.34 \%$ & $31.98 \%$ \\
\hline Sales & $204.97 \%$ & $196.08 \%$ & $175.01 \%$ & $101.97 \%$ \\
\hline \multicolumn{5}{|l|}{2000} \\
\hline Employment & $122.53 \%$ & $116.23 \%$ & $107.44 \%$ & $50.03 \%$ \\
\hline Value added per worker & $99.37 \%$ & $94.64 \%$ & $73.93 \%$ & $60.78 \%$ \\
\hline Capital per worker & $52.74 \%$ & $55.78 \%$ & $41.93 \%$ & $45.11 \%$ \\
\hline Average wages & $74.57 \%$ & $63.47 \%$ & $46.63 \%$ & $38.38 \%$ \\
\hline Sales & $232.61 \%$ & $222.84 \%$ & $191.71 \%$ & $120.28 \%$ \\
\hline \multicolumn{5}{|l|}{2001} \\
\hline Employment & $130.11 \%$ & $121.21 \%$ & $114.29 \%$ & $57.25 \%$ \\
\hline Value added per worker & $88.89 \%$ & $86.04 \%$ & $72.26 \%$ & $58.81 \%$ \\
\hline Capital per worker & $60.83 \%$ & $68.49 \%$ & $61.35 \%$ & $55.64 \%$ \\
\hline Average wages & $66.23 \%$ & $58.53 \%$ & $45.25 \%$ & $37.05 \%$ \\
\hline Sales & $227.53 \%$ & $218.36 \%$ & $196.15 \%$ & $122.58 \%$ \\
\hline \multicolumn{5}{|l|}{2003} \\
\hline Employment & $154.16 \%$ & $152.48 \%$ & $138.95 \%$ & $27.14 \%$ \\
\hline Value added per worker & $135.67 \%$ & $123.89 \%$ & $92.43 \%$ & $64.66 \%$ \\
\hline Capital per worker & $110.68 \%$ & $107.40 \%$ & $82.49 \%$ & $67.96 \%$ \\
\hline Average wages & $125.86 \%$ & $111.76 \%$ & $75.88 \%$ & $50.87 \%$ \\
\hline Sales & $301.01 \%$ & $289.62 \%$ & $240.68 \%$ & $95.12 \%$ \\
\hline
\end{tabular}

Note. All coefficients are significant at the 5 percent level or better. 
Table 4. Probit and logit estimation of exporter premia

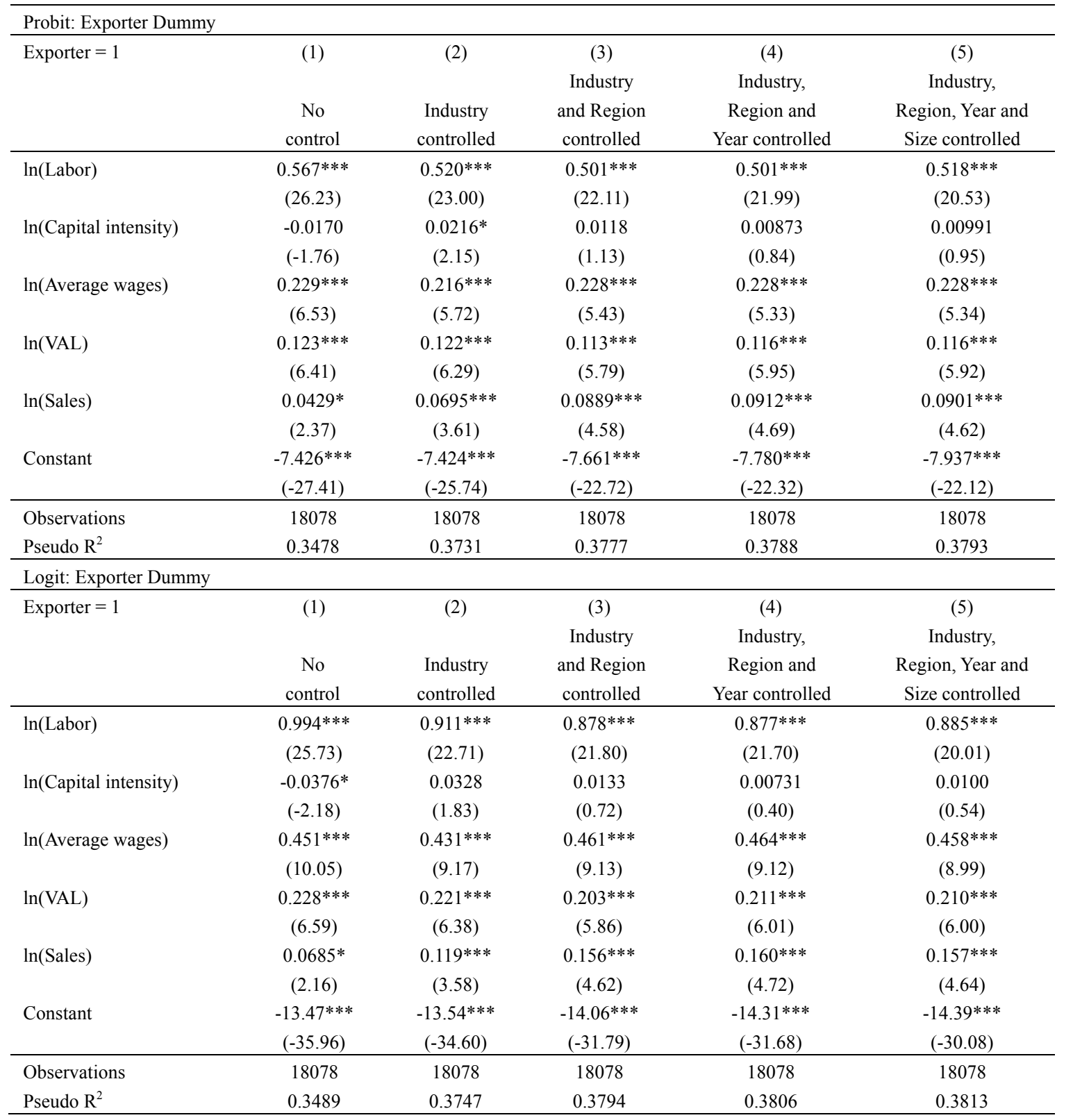

Note. Heteroscedasticity robust t-statistics in parentheses. $* * *, * *$, and * represent significance at $1 \%, 5 \%$, and $10 \%$, respectively. The numbers reported are estimated coefficients.

The approach used here is the same as the above method for estimating exporter premia. From Table 3, it is obvious from the results that importers also perform better than non-importers in every aspect. All coefficients on the import dummy variable are highly significant. Likewise, controlling industry and region exhibit little effect on the magnitude of the import premia. Nonetheless, controlling for firm size greatly decreases the coefficients of the import dummy variable, which implies that required characteristics of the importers are also due to their larger size. Controlling for industry, region, and size, importers have over 100 percent greater sales than non-importers. The value added per worker of importers is larger by approximately 50 to 60 percent, capital per worker by approximately 40 to 60 percent, and average wages by approximately 30 to 50 percent. More importantly, comparing results from Table 2 and Table 3, all coefficients on the import dummy variable are lower than those on the export dummy variable. This indicates that exporters perform better than importers, and importers perform better than firms that do not trade internationally. From the estimated results of Table 2 and Table 3, we can conclude that exporters are the most productive group of firms, followed by importers, while domestic firms (firms that do not trade at all) come last. For more insight regarding differences between these 
three types of firms, we move on to the next sub-section where we empirically estimate exporter premia and importer premia by probit and logit regressions.

\subsection{Probit/Logit Estimation for Exporter Premia and Importer Premia}

We now test further for exporter and importer premia by using probit and logit models to confirm and compare results from section 4.1 and 4.2 for all four years. In logit regression, the errors are assumed to have a standard logistic distribution. In probit regression, the errors are assumed to have a standard normal distribution. The probit and logistic regression models tend to usually produce similar results and predictions. However, parameter estimates in a logistic regression tend to be a little higher than they are in a corresponding probit model. This is also the case for our estimated results below. For our analysis, Table 4 shows the results for exporter premia and Table 5 shows the results for importer premia. Almost all coefficients are highly significant.

First, the results for probit and logit estimation of exporter premia are shown in Table 4. As expected, the logit estimates tend to be greater in magnitude when compared to the probit estimates. The estimated results again confirm that exporters outperform non-exporters in terms of various performance characteristics for both probit and logit models, even after controlling for industry, region, year, and firm size. Specifically, after controlling for industry, region, year, and size, exporters employ more workers, pay higher average wages, and have more value added per worker and sales. The overall results are consistent with previous studies. Surprisingly, the coefficients on capital per worker (capital intensity) are not significant for both probit and logit models. This is skeptical and may suggest that, during this period of analysis (1999-2003), exporting firms did not have to exhibit more capital per worker, in other words, exporters do not need to be capital-intensive firms in order to export.

Table 5. Probit and logit estimation of importer premia

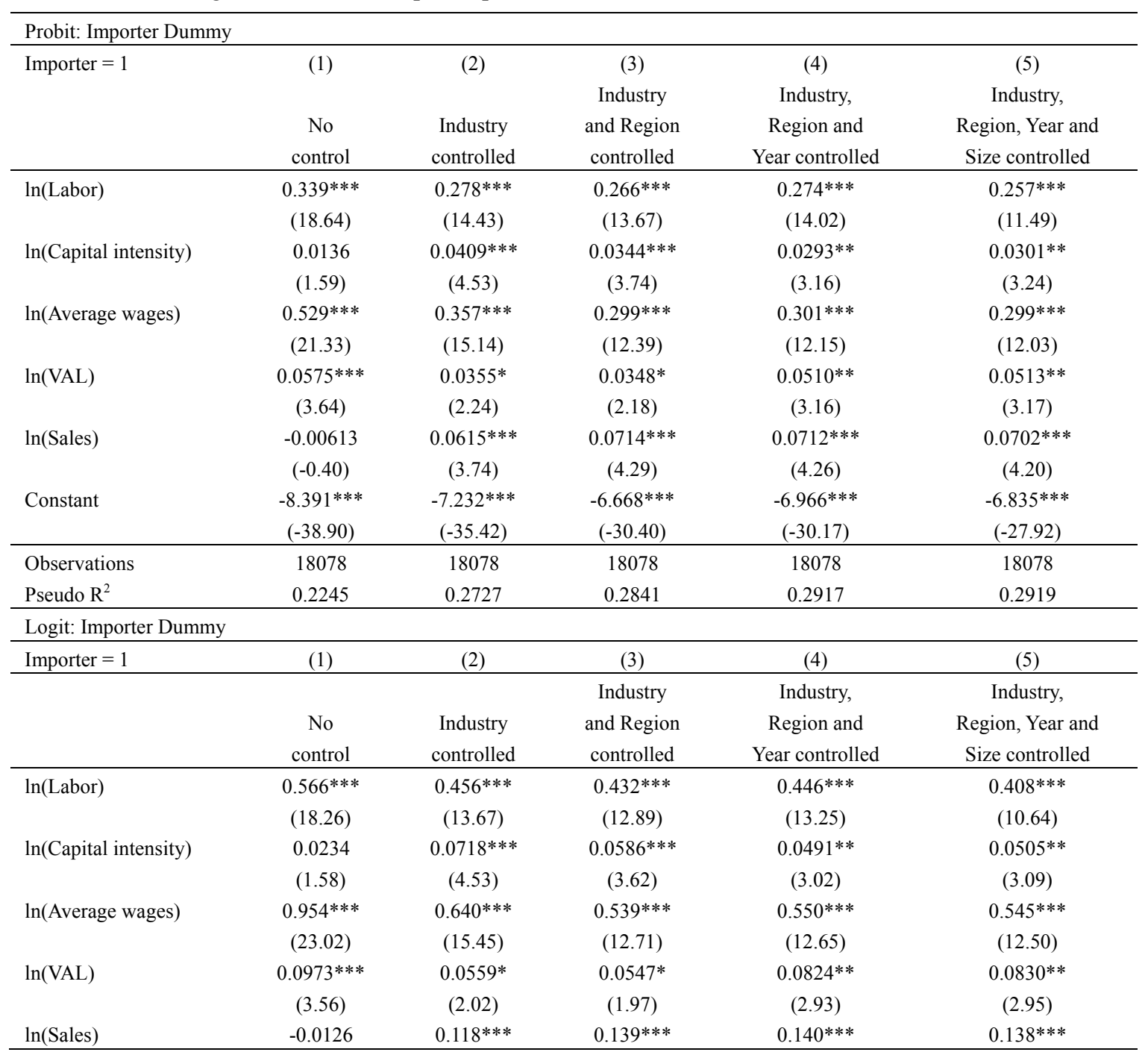




\begin{tabular}{lccccc}
\hline & $(-0.48)$ & $(4.14)$ & $(4.82)$ & $(4.83)$ & $(4.76)$ \\
Constant & $-14.79 * * *$ & $-12.79 * * *$ & $-11.85^{* * *}$ & $-12.45^{* * *}$ & $-12.15^{* * *}$ \\
& $(-39.95)$ & $(-34.98)$ & $(-30.25)$ & $(-30.39)$ & $(-28.14)$ \\
\hline Observations & 18078 & 18078 & 18078 & 18078 & 18078 \\
Pseudo R $^{2}$ & 0.2252 & 0.2735 & 0.285 & 0.2927 & 0.293 \\
\hline
\end{tabular}

Note. Heteroscedasticity robust t-statistics in parentheses. $* * *, * *$, and $*$ represent significance at $1 \%, 5 \%$, and $10 \%$, respectively. The numbers reported are estimated coefficients.

Second, Table 5 presents the results for probit and logit estimation of importer premia. Similarly, almost all coefficients on importer premia are less than those of exporter premia. This reveals that, on average, exporters perform even better than importers. Looking closely from the results shown in Table 5, importers also outperform non-importers in every aspect. Importing firms employ more workers, are more capital-intensive, pay higher average wages, exhibit more value added per worker, and have greater sales. Judging from Table 4 and Table 5, we confirm our previously estimated results in Table 2 and Table 3 that exporters are better than non-exporters, and importers are also better than non-importers. In particular, non-exporters and non-importers refer to domestic firms that do not trade internationally, and from the empirical results corresponding to terms of various performance characteristics, these firms do indeed perform worse than firms that export or import. Furthermore, when comparing between Thai manufacturing firms that trade, exporters generally perform even better than importers, as suggested by exporting firms normally exhibiting much higher sales, labor productivity (value added per worker), and employment of more workers.

\section{Does Exporting or Importing Improve Productivity?}

In this section, we attempt to initially test for evidence of the learning-by-doing hypothesis for the first time for Thai manufacturing, and seek an explicit relationship between productivity and two types of international trade activities: exporting and importing. A vast literature demonstrates by various measures that firms engaged in international trade as exporters or importers are more productive and perform better than firms which do not trade. For the Thai case, there have been extremely few comprehensive studies that have addressed this issue in detail. Our study here can be considered one of the first attempts to examine these relationships with the available data set. Following Bigsten and Gebreeyesus (2009), we first estimate a Cobb-Douglas production function and a logarithmic transformation yields the following equation:

$$
y_{i t}=\beta_{k} k_{i t}+\beta_{l} l_{i t}+\beta_{m} m_{i t}+\Phi_{i t}+\mu_{i t}
$$

where $K, L$, and $M$ are capital, labor, and intermediate inputs. $Y$ is output or value added per worker and $\Phi_{\mathrm{it}}$ is total factor productivity (TFP). Lower case indicates logarithmic values of the same variables and $\mu_{\mathrm{it}}$ is a pure random error. Commonly known to this kind of analysis, there is an apparent source of endogeneity. As a result, we assume that productivity evolves according to an autoregressive process and yields the following model:

$$
y_{i t}=\gamma y_{i t-1}+\beta_{k} k_{i t}+\beta_{l} l_{i t}+\beta_{m} m_{i t}+\zeta \text { exports }_{i, t-1}+\lambda X_{i t}+\omega_{i t}+\tau_{i t}
$$

where $X$ denotes control variables, $\omega_{\text {it }}$ denotes firm specific aspect of productivity, and $\tau_{\text {it }}$ is a pure random error. Specifically, our variable of interest is the prior export status. If $\zeta$ turns out to be positive and significant, learning-by-exporting effects may be occurring. The estimated results for exports and productivity are reported in Table 6 and results for imports and productivity are reported in Table 7 correspondingly.

The former part of Table 6 shows the results for the dependent variable being output and the latter part shows the results for the dependent variable being value added per worker. We use both types of dependent variable only to provide more reliable evidence and to compare the estimated results. In addition, we provide full estimated results from OLS (Ordinary Least Square), FE (Fixed Effects), and RE (Random Effects) estimations. The outcome according to Hausman tests indicates a significant P-value (below Table 6); as a result, it is appropriate to use estimated results from fixed effects as our benchmark results. As can be seen, the export dummy (firm's export experience) is positive and highly significant only for the case of dependent variable being value added per worker (VAL), suggesting that previous exporting may increase current productivity. The coefficients for age (firm's production experience) are not significant for both cases.

Next, the relationships between imports and productivity are presented in Table 7. In the same way, the outcome from Hausman tests also indicates a significant P-value (below Table 7); thus, we again use estimated results from fixed effects as our benchmark results. Comparing Table 6 and Table 7, we observe that the relationship between imports and productivity is somewhat weaker, and the import dummy (import experience) is positive and weakly significant only for the case of dependent variable being value added per worker (VAL). All other 
coefficients are line with the theoretical prediction and exhibit similar empirical results for both exports and imports. Importantly, the coefficient of the export dummy $\left(0.169^{* *}\right)$ in Table 6 is larger than the coefficient of the import dummy $\left(0.103^{* *}\right)$ in Table 7 . It is clear from the results that exports tend to affect productivity to a greater degree than do imports. The present results also confirm that exporting and importing firms generally perform better. Moreover, exports and imports may lead to an increase in productivity at the firm level in Thai manufacturing, with exporters revealing a stronger relationship with firm productivity than importers do. From our results, we can primarily conclude that there might be learning-by-doing effects (learning-by-exporting and learning-by-importing) for Thai manufacturing firms. Overall, exporting firms tend to outperform importing firms and exporting and importing firms significantly outperform firms with no trade.

Table 6. Exports and productivity

\begin{tabular}{|c|c|c|c|c|c|c|c|}
\hline \multirow{2}{*}{$\ln$ (Output) } & (1) & (2) & (3) & \multirow{2}{*}{$\ln (\mathrm{VAL})$} & (1) & (2) & (3) \\
\hline & OLS & $\mathrm{FE}$ & $\mathrm{RE}$ & & OLS & $\mathrm{FE}$ & RE \\
\hline L.ln(Output) & $\begin{array}{c}0.000460 \\
(0.14)\end{array}$ & $\begin{array}{c}-0.0271 * * * \\
(-3.93)\end{array}$ & $\begin{array}{c}0.000460 \\
(0.14)\end{array}$ & L.ln(VAL) & $\begin{array}{c}0.0000013 \\
(-1.15)\end{array}$ & $\begin{array}{c}-0.317 * * * \\
(-13.57)\end{array}$ & $\begin{array}{c}-0.0275^{*} \\
(-2.48)\end{array}$ \\
\hline $\ln$ (Capital) & $\begin{array}{c}0.0644 * * * \\
(11.68)\end{array}$ & $\begin{array}{c}0.0664 * * * \\
(7.82)\end{array}$ & $\begin{array}{c}0.0644 * * * \\
(11.90)\end{array}$ & $\ln ($ Capital) & $\begin{array}{c}0.145^{* * *} \\
(13.11)\end{array}$ & $\begin{array}{c}0.133^{* * *} \\
(7.93)\end{array}$ & $\begin{array}{c}0.145^{* * *} \\
(13.20)\end{array}$ \\
\hline $\ln$ (Labor) & $\begin{array}{c}0.207 * * * \\
(20.36)\end{array}$ & $\begin{array}{c}0.201 * * * \\
(14.01)\end{array}$ & $\begin{array}{c}0.207 * * * \\
(20.48)\end{array}$ & $\ln$ (Labor) & $\begin{array}{c}0.514 * * * \\
(25.64)\end{array}$ & $\begin{array}{c}0.410^{* * *} \\
(14.01)\end{array}$ & $\begin{array}{c}0.513^{* * *} \\
(25.94)\end{array}$ \\
\hline $\ln$ (Material) & $\begin{array}{c}0.750^{* * *} \\
(103.94)\end{array}$ & $\begin{array}{c}0.735^{* * *} \\
(73.98)\end{array}$ & $\begin{array}{c}0.750^{* * *} \\
(105.00)\end{array}$ & $\ln$ (Material) & $\begin{array}{c}0.448^{* * *} \\
(35.62)\end{array}$ & $\begin{array}{c}0.352^{* * *} \\
(19.90)\end{array}$ & $\begin{array}{c}0.448^{* * *} \\
(35.76)\end{array}$ \\
\hline Export(t-1) & $\begin{array}{c}0.00448 \\
(0.28)\end{array}$ & $\begin{array}{c}0.0492 \\
(1.78)\end{array}$ & $\begin{array}{c}0.00448 \\
(0.28)\end{array}$ & Export(t-1) & $\begin{array}{c}-0.00336 \\
(-0.11)\end{array}$ & $\begin{array}{c}0.169^{* *} \\
(3.27)\end{array}$ & $\begin{array}{c}0.0126 \\
(0.39)\end{array}$ \\
\hline lnAge(t-1) & $\begin{array}{c}0.00640 \\
(0.80)\end{array}$ & $\begin{array}{c}-0.00628 \\
(-0.44)\end{array}$ & $\begin{array}{c}0.00640 \\
(0.80)\end{array}$ & $\ln A g e(t-1)$ & $\begin{array}{c}0.0120 \\
(0.68)\end{array}$ & $\begin{array}{l}-0.0304 \\
(-1.07)\end{array}$ & $\begin{array}{c}0.0119 \\
(0.68)\end{array}$ \\
\hline Constant & $\begin{array}{c}2.789 * * * \\
(20.88)\end{array}$ & $\begin{array}{c}3.393 * * * \\
(10.75)\end{array}$ & $\begin{array}{c}2.841 * * * \\
(26.46)\end{array}$ & Constant & $\begin{array}{c}3.925 * * * \\
(11.58)\end{array}$ & $\begin{array}{c}10.23 * * * \\
(18.70)\end{array}$ & $\begin{array}{c}4.655^{* * * *} \\
(20.90)\end{array}$ \\
\hline Industry controlled & Yes & Yes & Yes & Industry controlled & Yes & Yes & Yes \\
\hline Year controlled & Yes & Yes & Yes & Year controlled & Yes & Yes & Yes \\
\hline Observations & 4425 & 4425 & 4425 & Observations & 4425 & 4425 & 4425 \\
\hline Adjusted $\mathrm{R}^{2}$ & 0.87 & 0.867 & & Adjusted $\mathrm{R}^{2}$ & 0.599 & 0.632 & \\
\hline
\end{tabular}

Note. Heteroscedasticity robust t-statistics in parentheses. ${ }^{* * *}, * *$, and $*$ represent significance at $1 \%, 5 \%$, and $10 \%$ confidence levels, respectively. FE stands for fixed effects estimates. RE stands for random effects. All coefficients for control variables are omitted to save space.

Panel A. Hausman tests for exports and productivity (in Table 6)

\begin{tabular}{|c|c|}
\hline \multicolumn{2}{|c|}{ Test: Ho: difference in coefficients not systematic (Dependent Variable: lnOutput) } \\
\hline $\operatorname{chi}^{2}(28)=56.05$ & Prob $>\mathrm{chi}^{2}=0.0013$ \\
\hline \multicolumn{2}{|c|}{ (Significant P-value, Prob $>$ chi $^{2}$ less than .05 , then it is safe to use fixed effects) } \\
\hline \multicolumn{2}{|c|}{ Test: Ho: difference in coefficients not systematic (Dependent Variable: $\operatorname{lnVAL}$ ) } \\
\hline $\operatorname{chi}^{2}(29)=562.60$ & Prob $>$ chi $2=0.0000$ \\
\hline \multicolumn{2}{|c|}{ (Significant P-value, Prob $>$ chi2 less than .05 , then it is safe to use fixed effects) } \\
\hline
\end{tabular}

Source. Author's calculation.

Notably for testing the links between productivity and trade (exports and imports) in our analysis, as the data at hand are still not rich enough to estimate the empirical model for other techniques, we could not directly apply the well-known method pioneered by Bernard and Jensen (1999a \& 1999b), or use other more sophisticated methods. Beyond this, the endogeneity problem in the analysis that might arise from unobserved heterogeneity can be successfully corrected by using instrumental variables, as in the recently developed system GMM (Generalized Method of Moments) approaches and many other extensions. Moreover, recent innovations in assessing learning-by-exporting (or importing) through group comparisons, matching methods (addressing selection bias via matching), are also ideal for detailed investigation for future examination.

Unfortunately, at the time of this study, there are no data that are rich and sufficient enough to effectively apply 
all of these advanced techniques for the Thai case. As a consequence, the present findings and results from this study should be taken as an innovative step for extensions in future research with richer data.

Table 7. Imports and productivity

\begin{tabular}{|c|c|c|c|c|c|c|c|}
\hline \multirow{2}{*}{$\ln$ (Output) } & (1) & (2) & (3) & \multirow{2}{*}{$\operatorname{Ln}(\mathrm{VAL})$} & (1) & (2) & (3) \\
\hline & OLS & $\mathrm{FE}$ & $\mathrm{RE}$ & & OLS & $\mathrm{FE}$ & $\mathrm{RE}$ \\
\hline L.In(Output) & $\begin{array}{c}-0.000453 \\
(-0.14)\end{array}$ & $\begin{array}{c}-0.0235^{* * *} \\
(-3.75)\end{array}$ & $\begin{array}{c}-0.000453 \\
(-0.14)\end{array}$ & L. $\ln (\mathrm{VAL})$ & $\begin{array}{c}0.0000012 \\
(-1.18)\end{array}$ & $\begin{array}{c}-0.309^{* * *} \\
(-13.73)\end{array}$ & $\begin{array}{c}-0.0284^{* *} \\
(-2.63)\end{array}$ \\
\hline $\ln$ (Capital) & $\begin{array}{c}0.0643 * * * \\
(11.67)\end{array}$ & $\begin{array}{c}0.0660 * * * \\
(7.74)\end{array}$ & $\begin{array}{c}0.0643 * * * \\
(11.89)\end{array}$ & $\ln ($ Capital) & $\begin{array}{c}0.145^{* * *} \\
(13.11)\end{array}$ & $\begin{array}{c}0.132 * * * \\
(7.86)\end{array}$ & $\begin{array}{c}0.145^{* * *} \\
(13.20)\end{array}$ \\
\hline $\ln ($ Labor) & $\begin{array}{c}0.207 * * * \\
(20.36)\end{array}$ & $\begin{array}{c}0.199 * * * \\
(14.01)\end{array}$ & $\begin{array}{c}0.207 * * * \\
(20.47)\end{array}$ & $\ln$ (Labor) & $\begin{array}{c}0.514 * * * \\
(25.67)\end{array}$ & $\begin{array}{c}0.419 * * * \\
(14.37)\end{array}$ & $\begin{array}{c}0.513^{* * *} \\
(25.95)\end{array}$ \\
\hline $\ln$ (Material) & $\begin{array}{l}0.751 * * * \\
(103.95)\end{array}$ & $\begin{array}{c}0.736^{* * *} \\
(74.89)\end{array}$ & $\begin{array}{l}0.751^{* * *} \\
(104.99)\end{array}$ & $\ln$ (Material) & $\begin{array}{c}0.449^{* * *} \\
(35.59)\end{array}$ & $\begin{array}{c}0.353^{* * *} \\
(20.02)\end{array}$ & $\begin{array}{c}0.448^{* * *} \\
(35.73)\end{array}$ \\
\hline $\operatorname{Import}(\mathrm{t}-1)$ & $\begin{array}{c}0.0148 \\
(1.01)\end{array}$ & $\begin{array}{c}0.0222 \\
(0.97)\end{array}$ & $\begin{array}{c}0.0148 \\
(1.03)\end{array}$ & $\operatorname{Import}(\mathrm{t}-1)$ & $\begin{array}{c}0.00834 \\
(0.29)\end{array}$ & $\begin{array}{c}0.103^{* *} \\
(2.26)\end{array}$ & $\begin{array}{l}0.0251 \\
(0.84)\end{array}$ \\
\hline $\ln A g e(t-1)$ & $\begin{array}{c}0.00682 \\
(0.85)\end{array}$ & $\begin{array}{c}-0.00676 \\
(-0.48)\end{array}$ & $\begin{array}{c}0.00682 \\
(0.86)\end{array}$ & $\ln A g e(t-1)$ & $\begin{array}{c}0.0119 \\
(0.67)\end{array}$ & $\begin{array}{l}-0.0307 \\
(-1.08)\end{array}$ & $\begin{array}{c}0.0123 \\
(0.70)\end{array}$ \\
\hline Constant & $\begin{array}{c}2.802 * * * \\
(20.78)\end{array}$ & $\begin{array}{c}3.355^{* * *} \\
(10.95)\end{array}$ & $\begin{array}{c}2.852 * * * \\
(26.84)\end{array}$ & Constant & $\begin{array}{c}3.921 * * * \\
(11.56)\end{array}$ & $\begin{array}{c}10.16^{* * * *} \\
(18.71)\end{array}$ & $\begin{array}{c}4.659 * * * \\
(21.11)\end{array}$ \\
\hline Industry controlled & Yes & Yes & Yes & Industry controlled & Yes & Yes & Yes \\
\hline Year controlled & Yes & Yes & Yes & Year controlled & Yes & Yes & Yes \\
\hline $\begin{array}{l}\text { Observations } \\
\text { Adiusted } \mathrm{R}^{2}\end{array}$ & $\begin{array}{l}4425 \\
0.87\end{array}$ & $\begin{array}{l}4425 \\
0.867\end{array}$ & 4425 & $\begin{array}{l}\text { Observations } \\
\text { Adiusted } \mathrm{R}^{2}\end{array}$ & $\begin{array}{l}4425 \\
0.599\end{array}$ & $\begin{array}{l}4425 \\
0.63\end{array}$ & 4425 \\
\hline
\end{tabular}

Note. Heteroscedasticity robust t-statistics in parentheses. ${ }^{* * *}, * *$, and $*$ represent significance at $1 \%, 5 \%$, and $10 \%$ confidence levels, respectively. FE stands for fixed effects estimates. RE stands for random effects. All coefficients for control variables are omitted to save space.

Panel A. Hausman tests for imports and productivity (in Table 7)

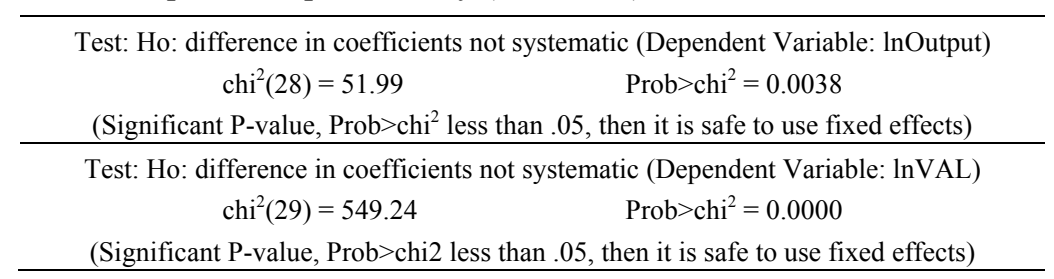

Source. Author's calculation.

\section{Concluding Remarks and Policy Implications}

Many studies confirm that exporting firms and/or importing firms are generally more productive than firms that sell or buy only in their domestic markets. This paper aims to empirically examine the relationship between exporting, importing and firm performance and productivity, using a firm-level panel data set from the Manufacturing Industry Survey of Thailand from 1999 to 2003. The main focus of this paper is to investigate whether or not exporters and importers actually outperform their domestic counterparts and whether learning-by-exporting/importing effects have occurred in Thai manufacturing. This is one of the first studies to primarily explore whether exporting and/or importing improves productivity at the firm level for the Thai case.

On average, the results show that exporters (and importers) are indeed more productive, more capital-intensive, have more employees and total sales, and pay higher average wages than non-exporters (and non-importers). Controlling for industry, region, year, and size effects, we find that exporting and importing firms still perform better than their domestic counterparts (i.e., firms which do not export or import) and all differences are highly and statistically significant. Often, exporters are the most productive type of firms, followed by importers and finally domestic counterparts. These results largely correspond with findings from other countries. Our evidence supports the fact that for the Thai case, exporters and importers are more productive and perform better than firms that do not trade internationally. The empirical evidence also reveals that there is a strong positive 
correlation between exporting and productivity, and a weak positive correlation between importing and productivity at the firm level, suggesting possible learning effects in both exporting and importing activities.

Our study sheds light on trade policy issues and provides empirical evidence that is necessary to evaluate various measures to promote exports and imports for manufacturing firms in Thailand. However, a fundamental caution in our analysis is related to the estimation of learning-by-doing effects. We cannot eliminate the fact that some direct tests of learning effects are missing from our estimates since the data at hand are not complete enough to formulate an empirical model for advanced techniques such as GMM approaches. Therefore, more work is needed to examine this issue to provide more evidence, especially in the case of newly industrialized and developing countries such as Thailand. Furthermore, since there is not enough information for two-way traders (firms that both export and import) in the data set after the data-cleaning procedure, the relationship between two-way traders and firm performance and productivity is also promising for future research.

Lastly, despite the desirable characteristics of exporting and importing firms, only a few manufacturing firms in Thailand are currently participating in the international market. This suggests that some potential exporters or importers may face barriers to exporting and importing activities. Since there might be learning-by-doing benefits in Thai manufacturing as revealed by the empirical results, there are good grounds for policy-makers to intervene to reduce these barriers. The export-oriented measures introduced long ago in Thailand seem sensible, but the government should further support export/import infrastructure such as the customs service, the administration of taxation, and so forth. The future challenge for policymakers will be harnessing these forces of market openness to ensure that the firm, and sector/industry as a whole, can raise its productivity and adapt to rising competition in the world market.

\section{Acknowledgments}

The author is grateful to Professor Masahiro Endoh for his guidance, Associate Professor Toshiyuki Matsuura for his support, Professor Hitoshi Hayami and Keio Economic Observatory (KEO) for providing the primary data set as well as members of the International Trade and Investment Seminar at Keio University for their help.

\section{References}

Arnold, J. M., \& Hussinger, K. (2005). Export Behavior and Firm Productivity in German Manufacturing: A Firm-level Analysis. Review of World Economics, 141(2), 219-243. http://dx.doi.org/10.1007/s10290-005-0026-8

Aw, B. Y., Chung, S., \& Roberts, M. J. (2000). Productivity and Turnover in the Export Market: Micro-level Evidence from the Republic of Korea and Taiwan (China). The World Bank Economic Review, 14(1), 65-90. http://dx.doi.org/10.1093/wber/14.1.65

Bernard, A. B., \& Jensen, J. B. (1999a). Exceptional Exporter Performance: Cause, Effect, or Both? Journal of International Economics, 47(1), 1-25. http://dx.doi.org/10.1016/S0022-1996(98)00027-0

Bernard, A. B., \& Jensen, J. B. (1999b). Exporting and Productivity. NBER Working Paper, 7135.

Bernard, A. B., \& Jensen, J. B. (2004). Why Some Firms Export. Review of Economics and Statistics, 86(2), 561-569. http://dx.doi.org/10.1162/003465304323031111

Bigsten, A., \& Gebreeyesus, M. (2009). Firm Productivity and Exports: Evidence from Ethiopian Manufacturing. The Journal of Development Studies, 45(10), 1594-1614. http://dx.doi.org/10.1080/00220380902953058

Clerides, S. K., Lach, S., \& Tybout, J. R. (1998). Is Learning by Exporting Important? Micro-Dynamic Evidence from Colombia, Mexico, and Morocco. The Quarterly Journal of Economics, 113(3), 903-947. http://dx.doi.org/10.1162/003355398555784

Fernandes, A. M., \& Isgut, A. E. (2005). Learning-by-Doing, Learning-by-Exporting, and Productivity: Evidence from Colombia. World Bank Policy Research Working Paper, 3544.

Girma, S., Greenaway, D., \& Kneller, R. (2004). Does Exporting Increase Productivity? A Microeconometric Analysis of Matched Firms. Review of International Economics, 12(5), 855-866. http://dx.doi.org/10.1111/j.1467-9396.2004.00486.x

Greenaway, D., \& Kneller, R. (2007). Firm Heterogeneity, Exporting and Foreign Direct Investment. The Economic Journal, 117(517), 134-161. http://dx.doi.org/10.1111/j.1468-0297.2007.02018.x

Hahn, C. H. (2005). Exporting and Performance of Plants: Evidence from Korean Manufacturing. International Trade in East Asia, NBER-East Asia Seminar on Economics, 14, 53-80. http://dx.doi.org/10.7208/chicago/9780226379005.003.0003 
Kohpaiboon, A. (2009). Vertical and Horizontal FDI Technology Spillovers: Evidence from Thai Manufacturing. ERIA Discussion Paper, 8.

Van Biesebroeck, J. (2005). Exporting Raises Productivity in Sub-Saharan African Manufacturing Plants. Journal of International Economics, 67(2), 373-391. http://dx.doi.org/10.1016/j.jinteco.2004.12.002

Wagner, J. (2007). Exports and Productivity: A Survey of the Evidence from Firm-level Data. The World Economy, 30(1), 60-82. http://dx.doi.org/10.1111/j.1467-9701.2007.00872.x

Wagner, J. (2012a). Exports, Imports and Profitability: First Evidence for Manufacturing Enterprises. Open Economies Review, 23(5), 747-765. http://dx.doi.org/10.1007/s11079-011-9235-z

Wagner, J. (2012b). International Trade and Firm Performance: A Survey of Empirical Studies since 2006. Review of World Economics, 148(2), 235-267. http://dx.doi.org/10.1007/s10290-011-0116-8

\section{Copyrights}

Copyright for this article is retained by the author(s), with first publication rights granted to the journal.

This is an open-access article distributed under the terms and conditions of the Creative Commons Attribution license (http://creativecommons.org/licenses/by/3.0/). 